\title{
The Problem of Law-Abiding Behavior among Minors in Educational Institutions: Domestic and Foreign Experi- ence
}

\section{El problema del comportamiento respetuoso de la ley entre los menores en las instituciones educativas: experiencia nacional y ex- tranjera}

Valentina B. Salakhova

Ulyanovsk State University, Ulyanovsk, Russia.

Center Research Security Problems the RAS, Moscow, Russia

ORCID: http://orcid.org/0000-0002-5056-6518

Natalia V. Belyakova

Russian State Social University, Moscow, Russia

ORCID: http://orcid.org/0000-0001-7116-9389

\section{Galina L. Knyazeva}

Moscow City University, Moscow, Russia

ORCID: https://orcid.org/0000-0002-4516-504X

\section{Lidiya B. Shneyder}

Moscow Pedagogical State University (MPGU), Moscow, Russia

ORCID: https://orcid.org/0000-0002-3517-0873

\section{Svetlana Yu. Schetinina}

Pacific National University, Khabarovsk, Russia

ORCID: https://orcid.org/0000-0003-0571-7329

\section{Zara A-M. Albakova}

Ingush State University, Magas, Russia

ORCID: https://orcid.org/0000-0002-2283-2030

\section{Marem T. Akhilgova}

Ingush State University, Magas, Russia.

ORCID: https://orcid.org/0000-0003-4765-1161

Received 07-14-20 Revised 08-30-20 Accepted 09-15-20 On line 09-25-20

*Correspondence

Email: Valentina_nauka@mail.ru
Cite as:
Salakhova, V.B., Belyakova, N.V., Knyazeva, G.L., Shneyder,
L.B., Schetinina, S.Y., Albakova, Z.A-M., Akhilgova, M.T.
(2020). The Problem of Law-Abiding Behavior among Minors
in Educational Institutions: Domestic and Foreign Experi-
encePropósitos y Representaciones, 8 (SPE3), e747. Doi:
http://dx.doi.org/10.20511/pyr2020.v8nSPE3.747 


\section{Summary}

At present, the problem of sustaining the law-abiding behavior of minors in educational institutions, identifying and eliminating the causes and conditions that contribute to the development of deviant behavior of students is becoming more and more topical. This paper presents the results of a monitoring study of the current state of the activities carried out by educational institutions to form the law-abiding behavior of minors in the territorial entities of the Russian Federation. It also presents the results of a theoretical study of the foreign experience of educational institutions in the framework of maintaining the law-abiding behavior of minors in the educational environment. The conclusions have been drawn that a system-activity approach should be the basis of an educational impact in educational institutions which will provide: the formation of students' readiness for self-development; the design and construction of a social environment for the development of students based on moral principles, traditional Russian values, relevant scientific knowledge and skills, respect for the traditions of the multinational, multicultural and multiconfessional Russian society; active educational and cognitive activities of students; building educational and moral education activity, taking account of the individual age-related psychological and physiological characteristics of students and with a focus on educational results. The materials of the paper are part of a large-scale study within the framework of the "Conception for the development of a system for the prevention of neglect and juvenile delinquency for the period up to 2020", conducted by a team of scientists from 2017 to 2020, whose scientific interests lie in the study of the problem of deviant behavior of minors.

Keywords: educational environment, law-abiding behavior, development of student's personality, system of prevention, psychological security.

\section{Resumen}

En la actualidad, el problema de sustentar la conducta respetuosa de la ley de los menores en las instituciones educativas, identificando y eliminando las causas y condiciones que contribuyen al desarrollo de conductas desviadas de los estudiantes se está volviendo cada vez más actual. Este artículo presenta los resultados de un estudio de seguimiento del estado actual de las actividades que realizan las instituciones educativas para formar el comportamiento respetuoso de la ley de los menores en las entidades territoriales de la Federación de Rusia. También presenta los resultados de un estudio teórico de la experiencia extranjera de las instituciones educativas en el marco del mantenimiento del comportamiento respetuoso de la ley de los menores en el ámbito educativo. Se ha extraído la conclusión de que un enfoque de actividad sistémica debe ser la base de un impacto educativo en las instituciones educativas que proporcione: la formación de la preparación de los estudiantes para el autodesarrollo; el diseño y la construcción de un entorno social para el desarrollo de los estudiantes basado en principios morales, valores tradicionales rusos, conocimientos y habilidades científicas relevantes, respeto por las tradiciones de la sociedad rusa multinacional, multicultural y multiconfesional; actividades educativas y cognitivas activas de los estudiantes; Construir una actividad educativa y de educación moral, teniendo en cuenta las características psicológicas y fisiológicas de los estudiantes relacionadas con la edad y con un enfoque en los resultados educativos. Los materiales del trabajo forman parte de un estudio a gran escala en el marco de la "Concepción para el desarrollo de un sistema para la prevención del abandono y la delincuencia juvenil para el período hasta 2020", realizado por un equipo de científicos desde 2017 al 2020, cuyos intereses científicos radican en el estudio del problema del comportamiento desviado de los menores.

Palabras clave: entorno educativo, comportamiento respetuoso de la ley, desarrollo de la personalidad del alumno, sistema de prevención, seguridad psicológica. 


\section{Introduction}

The formation of the law-abiding behavior of minors, the identification and elimination of the causes and conditions that contribute to the development of deviant behavior is one of the priority areas of activity of all subjects of the prevention system, including the bodies exercising control in the field of education and institutions carrying out educational activities. Law-abiding behavior is a stable behavior of a person, in which he follows the most important social norms, seeks to maintain public order and balance, while preserving his own individuality. Law-abiding behavior "works" owing to the self-control of an individual. Consequently, the content of the concept of "law-abiding behavior" contains a balance between accepting social norms, following them and maintaining an internal balance between a sense of duty and the actual behavior of an individual. It is important to understand that any behavior is shaped by observed patterns. The first step in forming the pattern of behavior is imitation (Kutuev et al., 2017). The system of education is the main institution for the socialization of minors, where personality development and the formation of values, attitudes, rules of behavior, legal competence in children and adolescents takes place that correspond to generally accepted norms of morality and ethics, current conditions of social development. In this regard, institutions engaged in educational activities ensure the formation of the law-abiding behavior of minors from the stage of imitation of normative behavior to the stage of the formation of law-abiding personality of an individual. Society sets high requirements regarding education, morality, responsibility of an individual, his ability to cooperate and compete, and the ability to independently make decisions in choosing various strategies of behavior. The legal and civic competence of an individual is the most important component of the general culture of a person, which his social and legal activity depends on, his willingness to participate in strengthening the rule of law and order. The statistics of juvenile delinquency and crime rate among minors, the facts of child abuse and domestic violence, and refusal to fulfill parental responsibilities have shown a steady downward trend in recent years. However, the nature of offenses, early age of offenders, a rise in the proportion of juvenile delinquency does not remove the significance of the activities of social institutions to prevent negative social phenomena. The improvement and development of the system of preventing juvenile delinquency should begin precisely with the system of education as the most important institution of socialization of children and adolescents' personality. To solve this problem, it is necessary to continuously improve the activities of educational institutions in the issues of forming law-abiding behavior of minors (Lekareva, 2017; Salakhova, 2018; Salakhova \& Artamonova, 2018; Vinogradova et al., 2018).

\section{Methodological Framework}

\section{The Analysis of Domestic Experience on the Problem of Organizing Activities Aimed at Forming Law-Abiding Behavior of Minors in Educational Institutions}

Recently, the mass media more and more often have published reports about the unlawful actions of minors related to crimes in the educational environment. Minors' offending in educational institutions demonstrate the failure of the educational component of educational institutions. It is the educational component that is the foundation for the development and formation of the personality of a teenager in general and the formation of norms and rules of behavior, in particular (Bodalev, 1996; Ilyin, 2009). Taking account of the fact that communication is the leading activity in teen years, the focus should be on the development of this category in the component of moral education. If communication between peers is always built independently, then communication "teacher-student" is undeservedly leveled out and excluded from the educational process, and thus carries the risk of missing both intrapersonal reactions and interpersonal behavioral acts of a deviant and delinquent nature (Salakhova et al., 2019; Efimova et al., 2018).

Pedagogical communication within the educational process occurs every day, but the level of personal and informal communication of participants in the educational process de- 
creases. Meanwhile, communication is a complex and multifaceted process, which belongs to one of the major (basic) human needs (Myasishchev, 1970). This form of activity, carried out between people as equal partners and leading to the emergence of mental contact, is the main way of interaction between people (Andreeva, 2007).

Communication functions comprise 3 components: communication (exchange of information), interaction (exchange of actions), and social perception (perception and understanding of a partner). The modern communication situation is further complicated by the fact that the major part of these three components have moved to the virtual world. Some teenagers find it easier to communicate while at the monitor screens than to find themselves in a real situation of interaction: the communicative function of communication has been almost completely transferred to the Internet environment.

Due to the fact that the process of communication is aimed at meeting the needs of a teenager, a key role in the correct organization of this process is assigned to its form and the quality of this interaction. The communication process is based on three equivalent categories: content, purpose and means. The content of communication consists in the exchange of information between the participants in the process by means of coding, transmission, processing and decoding of information in order to satisfy various needs: social, cultural, cognitive, creative, aesthetic, intellectual growth and moral development, etc. Teenagers, striving to fulfill the need for communication, use the arsenal of means that they have learned in the process of socialization starting from preschool age: first of all, the family, then the kindergarten, and, then the school. All this is the environment from which the teenager draws knowledge, interiorizing and transforming it into skills. To be able to change these skills, a long and painstaking work is required to teach new ways of interaction, including communication. Therefore, an important aspect of prevention is the increase in the number of effective programs for the formation of the law-abiding behavior among minors. That is why, for the successful work of students, the educational environment must be safe, healthy and properly organized. For this purpose, it is necessary to create a climate of respectful attitude in the school that excludes any disorganization or deviant behavior of students: violence, drug use or addictive behavior.

The psychological service can act as a possible resource of maintaining a favorable climate in an educational institution, focused, inter alia, on work to prevent juvenile delinquency. Services can become the foundation for effective management in planning its development, increasing the effectiveness of its activities, as well as developing regional social projects, professional training programs for educational psychologists for the system of education and postdiploma guidance.

In such a difficult period for a teenager, it is important to have an adult who could share his experiences, emotions and thoughts with him. This person may be a parent, an educator, a psychologist, a social educator or a teacher. Such communication requires time, which can be laid in the framework of extracurricular activities. If a teenager is in a state of stress, suffers from baiting, victimization or domestic violence, and the need for communication is not satisfied, he verbally or non-verbally: through electronic technology, informs others about it. It is important that in this alarming situation, staff members of educational institutions provide qualified professional assistance (Kalinina et al., 2018).

The development of the psychological service should contribute to an increase in the number of professional development programs and professional training programs in educational institutions. These programs are intended for raising the awareness of teaching staff regarding the prevention of deviant behavior among minors. This is possible if extracurricular activities are available, within which staff members can conduct activities of various forms.

In addition, today there is an insufficiently coordinated mechanism of interdepartmental interaction and the unwillingness of the divisions of one department to respond and act promptly and productively in relation to preventive measures to stop juvenile delinquency. 
Thus, the main range of problems sprang up in organizing activities aimed at forming the law-abiding behavior of minors in educational institutions (Salakhova, 2019; Maltseva et al., 2020), namely:

- exclusion of the moral education component from the educational process;

- elimination of extracurricular activities, as well as transferring them to a commercial basis at the expense of the parent community;

- displacement of such an important process as communication (interpersonal and intergroup), thereby not meeting the basic need;

- shortage of human resources, as well as insufficient level of their qualifications;

- a small number of professional development programs for executives and staff of educational institutions;

- insufficient number of effective preventive programs for minors to form law-abiding behavior, prevent violence (including domestic violence), victimization, bullying and crime;

- a lack of psychological services in educational institutions;

- a weak level of penetration of interdepartmental ties and the fragmented activity of intradepartmental divisions;

- a lack of sufficient funding to carry out effective work to prevent juvenile delinquency in educational organizations.

The listed problems have a multifaceted nature and cannot be resolved in the short run. However, solving some problems is a priority action for further building an effective educational process. This is a priority solution to such problems as: strengthening the ties of interdepartmental interaction, creating a psychological service in educational institutions, placing the moral education component in the mainstream of the educational process and developing the younger generation through the integration of moral education, learning and extracurricular processes in the educational process. In addition, an attainable indicator of the effectiveness of the educational process seems to be an increase in the number of professional development programs for executives and staff of educational institutions, as well as deviant behavior prevention programs for minors.

\section{Results and Discussion}

\section{Deviant Behavior Prevention Programs (Domestic Experience)}

Federal state standards, the conception of Spiritual and moral development and education of the personality of a citizen of Russia and Federal Law No. 120-FL of June 24, 1999 "On the foundations of the system of preventing neglect and juvenile delinquency" serve as the methodological basis for the organization of psychological and pedagogical activities aimed at forming the law-abiding behavior of minors, as well as preventing deviant behavior of students in educational institutions of Russia (Trubitsyna, 2012; Salakhova \& Artamonova, 2018). These federal documents are interconnected - the main result of the implementation of the Federal State Educational Standard is the spiritual and moral development and education of the personality of a graduate. The Federal State Educational Standard and the conception of spiritual and moral development and education of the personality of a Russian citizen is the basis of values and regulations for the interaction of educational institutions with other subjects of socialization - the family, public organizations, religious associations, institutions of additional education, culture and sports, and the media. The purpose of this interaction is to jointly provide conditions for the spiritual and moral development and education of students, their successful socialization (Improvement of the system of prevention of offenses of minors in educational institutions Saint Petersburg, 2012). These goals today serve as the methodological foundation for organizing ac- 
tivities focused on shaping the law-abiding behavior of minors and preventing juvenile delinquency.

The development of the state governed by the rule of law, the formation of civil society and strengthening national concord in Russia require that citizens should possess a high legal culture without which such basic values and principles of the life of society as the supremacy of law, the priority of a person, his inalienable rights and freedoms, and ensuring reliable protection of public interests cannot be fully realized.

The Fundamentals of State Policy of the Russian Federation in the field of development of legal literacy and legal awareness of citizens (hereinafter - the Fundamentals) were adopted for the purpose of forming a high level of legal culture of the population, the tradition of unconditional respect for the law, order and justice, integrity and conscientiousness as the predominant model of social behavior, as well as overcoming legal nihilism in society, which hinders the development of Russia as a modern civilized state. In particular, it was determined in the Fundamentals that the main goals of state policy in the development of legal literacy and legal awareness of citizens are (Rybalkina, 2013):

1) the formation of sustainable respect for the law and overcoming legal nihilism in society;

2) increasing the level of legal culture of citizens, including the level of awareness and legal literacy;

3) the creation of a system of incentives for obedience to the law as the principal model of social behavior;

4) cultivating the idea of conscientious performance of duties and compliance with legal norms in the public consciousness.

The formation of law-abiding behavior is an organized, systematic, purposeful influence on a person which forms legal consciousness, legal attitudes, skills and habits of active lawful behavior.

Organization principles:

- a systematic and differentiated approach to students;

- activation of students' interest in acquiring legal knowledge;

- linking legal information with facts from everyday life of students, teaching them to consciously evaluate their actions;

- ensuring the conscious mastering of legal knowledge;

- taking into account the psychological and age characteristics of students.

Legal knowledge contributes to the correct understanding of social phenomena, contributes to the development of social activity of citizens, makes it possible to orient oneself correctly in life, to draw the line between what is permitted and what is prohibited, to choose legal ways and means of protecting personal rights and interests.

The formation of law-abiding behavior should contribute to the formation of a specific legal conceptual apparatus of thinking, with the help of which the selection, classification and processing of legal information coming from outside are carried out. The formation of such a conceptual apparatus is one of the most important tasks of legal education of school students; only with its help it is possible to develop the ability for independent, correct and conscious mastering of legal knowledge. The ability to correctly and consciously perceive legal information and the phenomena of legal reality is a necessary condition for both legal education and legal breeding of an individual (Methodical recommendations on legal education in educational institutions, 2015; Semyonova \& Belonenko, 2016). 
The analysis of the information in our monitoring of domestic literature on this issue showed that a large number of large scale events are held in territorial entities of the Russian Federation to form law-abiding behavior (scientific conferences; discussion platforms; regional and municipal exhibitions of visual and programmatic materials on the dissemination of information on the rights of the child in the media, the information and telecommunications network "Internet" in order to cover this issue with a larger number of students, parents, specialists working with children and in the interests of children). In many territorial entities of the Russian Federation, the formation of law-abiding behavior occurs in the process of teaching academic subjects. The development and implementation of additional general education programs is encouraged (Bolelova \& Lekareva, 2016); the activities of specialized classes with in-depth study of law are organized.

In general, in the Russian Federation, both forms and methods of forming the lawabiding behavior of students that have been established for many years, and non-traditional forms of legal education are used. Olympiads organized for students on legal topics, class hours, thematic meetings with law enforcement officers, competitions of projects on legal education among children and youth, excursions, and research circles have also become widespread. Specialized secondary educational institutions, cycles of seminars on the development of legal competences are widely organized It has already become traditional for parents of students to participate in thematic parent meetings, lectures, family. Olympiads on legal issues. Training webinars (online seminars) with students, parents, educators, representatives of civil society and specialists from the agencies supervising education have also become widespread in the regions. In order to embrace a larger number of students, parents, specialists working with children and in the interests of children on the formation of law-abiding behavior topical issues of legal education for children, parents, specialists are published on the official websites of regional and municipal bodies supervising education. In a number of regions, there are interdepartmental special pages dedicated to legal education. In addition, work is underway to prepare, publish and distribute printed materials containing information on the rights of the child, adapted for children, parents, teachers, professionals working with and in the interests of children. Reference books and methodological recommendations for teachers on the issues of legal education of students are being developed (Bolelova \& Lekareva, 2016).

Printed brochures, memos, information leaflets, information booklets and their electronic versions are developed and distributed for the purpose of expanding the possibilities of educational activities on the formation of law-abiding behavior in the territorial entities of the Russian Federation. Visual aids of legal campaigning are also used at book exhibitions dedicated, for example, to the Convention on the Rights of the Child, when decorating information booths about the rights and obligations of children, when showing videos on legal topics.

\section{Deviant Behavior Prevention Programs (Foreign Experience)}

To help executives of educational institutions make decisions about the launch of school safety programs, the National Institute of Justice (NIJ) has evaluated over 100 bullying prevention programs that address violence against women. In addition, the National Institute of Justice proposed Comprehensive School Safety Initiative (CSSI) which is a research-oriented initiative that aims to develop knowledge of the root causes of school violence, develop strategies to improve school safety, and rigorously evaluate innovative school safety strategies through pilot programs.

The outcome of the work of the institutions concerned was the development of programs focused on the prevention of deviant behavior among minors, as well as the prevention of the use of psychoactive substances and drugs. The four most effective programs presented on the official website are used as examples (Elkonin, 2007). 
For example, one of the programs is called Linking the Interest of Families and Teachers (LIFT). The program is designed to prevent the development of aggressive and antisocial behavior among children of primary school age. The intervention group showed less physical aggression of the child, reduced initiation of the use of psychoactive substances; and although the entire sample showed a significant average increase in the growth of substance consumption over time, the intervention slowed down the rate.

The program called "Positive Action" was recognized as another effective program.

Research in the framework of this program was carried out more than once, and gave its positive results, which allowed experts to evaluate this program as effective.

The program is designed to improve learning, behavior and character among young people and can also be used by schools, families or communities. Students receiving treatment reported less substance use, problem situations, and violent behavior in comparison with the control group. In addition, the level of bullying (baiting) according to the subjective feelings of the respondents decreased to $41 \%$. The results concerning sexual activity and aggressive behavior were not statistically significant.

One of the school programs featured on the Bureau of Prevention website for middle and high school students aims to stop or prevent early victimization and violence. It is called "Safe Dates." This program showed a moderate effect of victimization treatment and a reduction in physical abuse.

The adolescents in the first group reported that they commit less psychological and sexual abuse in all four periods of observation, compared to the youth in the control group.

The School-Wide Positive Behavioral Interventions and Supports (SWPBIS) program, which has been repeatedly implemented in educational institutions, has demonstrated effectiveness in the prevention of juvenile delinquency (Stubbs Richardson, 2018). This is a universal school prevention strategy focused on reducing behavioral problems that lead to instilling school discipline, as well as changing perception of school safety.

Students of educational institutions where this program was conducted received significantly fewer school restrictions than adolescents in schools that did not provide training on the basis of this program. Perceptions of safety improved in schools that implemented SWPBIS but declined in educational institutions that did not offer the program.

In addition to the active introduction of prevention programs to reduce victimization and juvenile delinquency, educational institutions in the United States are actively using best practices that raise the level of school performance and contribute to the reduction of absenteeism cases in school, as well as the expulsion of certain groups of people from educational institutions. This is the so-called "Dropout Prevention Programs": School or community programs for pupils or students who are often absent or at risk of leaving an educational institution. They are directed at raising the number of teenagers involved in extracurricular activities, increasing their school activity and academic performance. The main goal of these programs is to increase graduation classes. This program is effective in reducing student dropout rates and assessing prospects for improving test / grade scores, coursework and attendance.

Often the cause of juvenile delinquency and delinquent behavior is domestic violence, which entails violent crimes against peers and other people. Apart from this, such family relationships can lead to early victimization of a teenager, that is a way of avoiding traumatic reality and bad experiences. Programs of school interventions to reduce accidents and sexual violence increase learners' knowledge of healthy lifestyles and law-abiding behavior. This practice includes prevention programs and interventions at all levels in schools that aim to reduce or prevent violence against teenagers and early victimization. This practice is designed to reduce the 
incidence of violence among teenagers and adolescents and improve familiarity with nonviolent and violent relationship skills. However, there is no evidence of an effect of reducing victimization among teenagers.

School-based Social and Emotional Learning (SEL) programs are designed to develop five interrelated sets of cognitive, affective, and behavioral competences to provide the foundation for better adaptation and academic performance in students, which can lead to more positive social behavior, fewer behavioral problems, and less emotional stress. The practice was assessed as effective in reducing student behavior problems and emotional stress.

One of the problems in the behavior of minors is the inability to properly deal with their own aggression. As part of the professional development of teachers, the "Practice of Universal Learning for Teachers" is carried out. It covers methods and programs for class management to breed socially desirable behavior and reduce or prevent unwanted or aggressive behavior of students in high school. This practice has turned out to be effective in reducing destructive, inappropriate and aggressive behavior in learners.

\section{Conclusion}

The analysis of the best practices and effective programs for the prevention of juvenile delinquency in educational institutions showed that the greatest effect was demonstrated by those programs that embraced in their structure all the components of the teenager's microsocial and macrosocial media, namely: parents or relatives of adults, peers, staff members of educational institutions, representatives of reference communities and other subjects that play an important role in the life of a teenager. In addition, programs aimed at teaching nonviolent skills, as well as the ability to resist and prevent violence, were found to be highly effective. This suggests that some teenagers and adolescents do not know how to behave properly to resist violence and aggression, and also do not know how to use communication as a resource for effective interaction. Such prevention programs are intended to teach this. Thus, both foreign and domestic educational institutions encounter problem issues and "blind spots" requiring cardinal management decisions in the field of public education policy. However, the experience of foreign countries suggests that small changes and adjustments in the educational process contribute to an increase in performance indicators due to a well-planned process of interdepartmental and intradepartmental interaction. In addition, building human resources and raising the level of qualifications through the development and implementation of professional development programs for executives and staff members of educational institutions is a favorable factor in improving the level and quality of education.

Regarding the educational process itself, it is necessary to include such a basic need as communication in the triad: moral education process, learning process and extracurricular activities. The comprehensive nature of this approach to the educational process will increase the level of crime prevention among minors, as well as prevent victimization and violence by increasing the level of knowledge of teenagers, and, owing to prevention programs, it will be possible to reduce the level of aggressive behavior, and train in interpersonal and intergroup communication skills.

One can also draw a conclusion that a system-activity approach should be the foundation of educational impact in educational institutions that will provide:

- the formation of students' readiness for self-development;

- designing and constructing a social environment for the development of students on the basis of moral principles, traditional Russian values, relevant scientific knowledge and skills, respect for the traditions of the multinational, multicultural and multiconfessional Russian society; 
- active educational and cognitive activity of students;

- construction of learning and moral education activities, taking account of the individual age-related psychological and physiological characteristics of students and with a focus on educational results (Salakhova, 2018).

Moreover, cooperation and equal partnership should be the foundation block of this activity which can create favorable conditions for the formation of law-abiding behavior in children and adolescents. The implementation of a comprehensive approach to the organization of all psychological and pedagogical work with students will ensure their inclusion in the life of civil society, their participation in the work of student self-government and maximum involvement in the activities of various public associations.

Moral education of a citizen implies a conscious and responsible observance and implementation of life rules, norms and laws of society. The higher the level of such development, the more effectively a person is able to defend his constitutional rights and responsibly fulfill his rights and obligations. The major goal of such activity is to form a civic moral stance of an individual who is capable of bearing moral responsibility for his decisions, taken in view of the system of values existing in this society and knowledge of legal laws. Purposeful development of moral norms and values by the younger generation, which are the foundations for the formation of a conscious member of society, will create the prerequisites for the development of forms of law-abiding behavior. In the process of specially organized work, society receives a morally stable person, a socially active, legal and culturally literate and law-abiding citizen of the state. At the same time, a high level of moral development helps a child deal with complex socioeconomic problems, understand the socio-political life of the country, having his own opinion and defending his own stance, while focusing on the internal moral values in accordance with which a person lives (Salakhova, 2018).

\section{Acknowledge}

This publication was prepared with the financial support of the grant of the President of the RF № МК-2074.2019.6.

\section{References}

Andreeva, G.M. (2007). Social Psychology. Moscow: Aspect Press.

Bodalev, A.A. (1996). Psychology of Communication: Selected Psychological Works. Moscow: Institute of Practical Psychology. Voronezh: NPO MODEK.

Bolelova, A.G., \& Lekareva, E.E. (2016). Legal education in the education system: monitoring research. Personality formation, 4, 147-154.

Efimova, O.I., Salakhova, V.B., Oshchepkov, A.A., Khudyakova, T.L., \& Deberdeeva, N.A. (2018). Antisuicidal Potential of the Person: Theory and Empirics Research. Modern Journal of Language Teaching Methods, 8(5), 510-517.

Elkonin, D.B. (2007). Child psychology. Moscow: Publishing Center "Academy".

Ilyin, V.P. (2009). Psychology of communication and interpersonal relations. St. Petersburg: Peter.

Improvement of the system of prevention of offenses of minors in educational institutions Saint Petersburg. (2012). URL: https://spbappo.ru/wpcontent/uploads/2018/07/Texnologii_profilaktiki_pravonarushenij_108.pdf. St. Petersburg: Government of St. Petersburg, Education Committee.

Kalinina, N.V., Zaretskiy, V.V., Salakhova, V.B., Artamonova, E.G., Efimova, O.I., \& Lekareva, E.E. (2018). Psychological and pedagogical resources of security provision and prevention of internet risks and life threats among children and teenagers in the educational environment. Modern Journal of Language Teaching Methods, 8(8), 118129. 
Kutuev, R.A., Mashkin, N.A., Yevgrafova, O.G., Morozov, A.V., Zakharova, A.N., \& Parkhaev, V.T. (2017). Methodological guidance of educational monitoring effectiveness. Modern journal of language teaching methods, 7(3), 405-410.

Lekareva, E.E. (2017). Software, methodological and information support of legal education in the education system. Personality formation, 3, 108-115.

Maltseva, O.V., Shulga, T.I., Kazakova, S.N., Kosolapova, N.V., Mironenkova, O.L., Belyakova, N.V., \& Shabanova, O.V. (2020). Features of Forming Minors' Law-Abiding Behavior: A Socio-Psychological Aspect. International journal of applied exercise physiology, 9(4), 132-138.

Methodical recommendations on legal education in educational institutions. (2015). URL: https://p.120-bal.ru/pravo/21341/index.html. (Date of Access: 20.05.2020)

Myasishchev, V.N. (1970). On the relationship of communication, attitude and reflection as a common problem in social psychology. Socio-psychological and linguistic characteristics of communication and the development of contacts between people: Abstracts of the symposium, pp. 114-116. Leningrad.

Rybalkina, A.V. (2013). Legal culture and its perception by students. Materials of the II AllRussian (with international participation) scientific and practical conference "Culture and society: history and contemporary» O.Yu. Kolosova, R.F. Gudarenko, N.A. Ryasnyanskaya, E.A. Krasikova. Stavropol, April 10.

Salakhova, V.B. (2018). Guidelines to improve the activities of educational organizations to form law-abiding behavior of minors. URL: https://fcprc.ru/wpcontent/uploads/2019/06/Informatsionno-metodicheskie-rekomendatsii_p.14.pdf. (Date of Access: 05.06.2020)

Salakhova, V.B. (2019). Improvement of the system for prevention of outstanding and offenses of minors in the territory of subjects of the Russian Federation. Simbirsk scientific journal vestnik, 4(38), 59-71.

Salakhova, V.B., \& Artamonova, E.G. (2018). Improvement of activities of educational organizations for formation of the law-expressed behavior of minors. Personality formation, 3, 70-78.

Salakhova, V.B., Sokolovskaya, I.E., Ulyanova, I.V., Karina, O.V., \& Terekhova, A.I. (2019). Deviant behavior formation factors among students: aggressive behavior and internet risks. Práxis Educacional, 15(34), 683-694.

Semyonova, S.A., \& Belonenko, I.V. (2016). Educational process in a secondary vocational educational institution. Innovative Science, 10(2), 193-207.

Stubbs Richardson, M.S. (2018). Making a decision to retreat, relate, or retaliate: An examination of theoretical predictors of behavioral responses to bullying in a high school setting. URL: https://pqdtopen.proquest.com/pubnum/10979110.html?FMT=AI. (Date of Access: 08.05.2020)

Trubitsyna, E.V. (2012). Civil legal culture of school children - the way to social success. I. Yakovlev Chuvash state pedagogical university bulletin, 1(73), 167-172.

Vinogradova, G.A., Akhmadieva, R.Sh., Konovalova, V.M., Spirina, E.V., Kalugina, O.A., Erdyneeva, K.G., Popova, N.N., \& Mashkin, N.A. (2018). Releasers as Factor of Student Ecological Focus Formation. Ekoloji, 27(106), 1409-1415. 